\title{
Some Characteristics of Islamic Journalism Based on Al Quran
}

\author{
M. Yoserizal Saragih \\ State Islamic University of North Sumatra (UINSU), Medan, Indonesia \\ :yosesaragih@gmail.com
}

\begin{abstract}
Prophet Mubammad $S A W$ as a role model has been made and gives examples of how the application of journalism itself. Prophet does his message through writing, that is, when he sends a letter to the kings or heads of tribes in Madinah in order to invite to the road of Islam. A journalist should be able to convince mad'u let that propaganda purposes can take place without any problem. Journalistic as a method in a very strategic propaganda . Beside it can be enjoyed by many people, the product of journalism also can be more lasting or durable, because it can be stored or read anytime. Journalism propagation of Islam is actually not a new method of propaganda, because the Prophet has implemented a method of propaganda by sending a letter of propaganda to the kings who do not know and embrace Islam.
\end{abstract}

Keywords: Al Quran; journalism; characteristics; news

\section{INTRODUCTION}

Recently, the development dissemination of Islam tends to increase either through electronic media, as well as print media. Almost every day, even during the holy month of Ramadan, we could follow the broadcasting of Islam in all national TV stations. Speakers with his style that captivated interspersed with slang are trendy today supported with depth science they have. Presentation the development of Islam on TV, as the writer explains above, is more attractive to the public because it is visual. Beside audio visual, audio is also can be used to interact the audiences. From these ways, the method of delivery of messages should be packaged well and beautifully so that the public can receive the result of the presence of the journalism.

Islam means the spread of da'wah. Da'wah does not only mean lecturing as a traditional way, but can use a variety of modern facilities in other not out of date. The core of da'wah to bring people to Allah can be achieved. Journalism as a tool has a very powerful effect though it may 
appear slower, but leaves a deep impression. The essence of da'wah through journalism does not merely convey messages, but also a particular focus on what will be happened after finishing reading the media on the results of earlier journalistic product. For that, man is not only influenced by words but also the power of writing in relation to the language of da'wah. The words (text) can be a thing that stimulates the psychological response of man, and it is caused by several things:

The power of writing in relation to the language of da'wah that is persuasive, namely the words (text) that will be the thing stimulates psychological response of man, and it is caused by several things, that is:
a. The beauty of the language
b. Clarity of information
c. The logic is very strong
d. Provide hope
e. Provide a warning

\section{REVIEW OF LITERATURE}

\subsection{Definition of Mass Media}

Mass media is a tool used in conveying the message from the source to the audience by using mechanical means of communication, such as newspapers, radio, television and etc. In this case, here the mass media is print media or newspapers. According to Bitter (in Muhtadi, 1999: 73), mass media is a means of transmitting information, such as newspapers, magazines, books, films, radio and television, or a combination of shapes of media forms. Meanwhile, according to Cangara (2002: 134), mass media is a tool used in the delivery of a message from the source to the audience (receiver) using a mechanical of communication such as newspapers, radio, film and television.

Newspaper is a term for press publications which are included in the printed mass media, news sheets come into one's vision, a bouquet of coral and advertisements published periodically, daily, weekly, monthly, and distributed in general. Its contents must be actual, universal, purpose preaching should be concerned with a variety of people and groups. By type, the newspaper is two daily mail and newspapers periodically (weekly, biweekly, monthly and so on). Newspaper is one that is quite important for the community, the newspaper is a journalistic print media. The above 
statements, expert opinion can be made formulation that letter used to notify an event, place and specific events in the form of translation of words that contain the main ideas so easily understood by others. These ideas into a single entity that cannot be separated, thus giving birth to interesting information to be read by everyone, especially for readers. Newspaper has a lot to provide information ranging from editorials, news of politics, economy, education, culture, health, sports, and articles. In terms of writing, newspapers uses $5 \mathrm{~W}+1 \mathrm{H}$ or the so-called ten guidelines for writing. Consider the newspaper published today that come to your home or to your office, from the first page to the last page, he will give a lot of problems and information.

\subsection{Conducting Propagation Institute of Journalism}

The point is that social institutions who work in the field of Da'wah Islamiah in this case his message reach the goal using journalistic methods. Such institution, there are two kinds, namely a special method that uses journalism and journalistic methods in addition to other communication methods in achieving the goals preaching. Institutions using the special propaganda journalism, in his message does not reach the goal using the method other than journalism. Hence the structure is embraced by the press. It's just all the special nuances Islam. The difference is journalistic product contained in the division (desk) editor is based on fields of Islamic teachings such as desk aqidah, worship desk, muamalah, and so forth. While the editorial desk in the press based on the areas of human life generally like sports desk, desk criminal, economic, political desk, and so on. However the shape of the press as it has been expressed before. Institutions that use propaganda journalism in addition to other methods to achieve the goal of preaching is evident not only specialize in journalism, but many other methods in use. In addition to journalism, it can be used educational methods, implementation, propaganda, indoctrination, and so forth.

Its shape structure follows the structure of its parent organization. Journalistic activities only handled by one part and the parent organization. Like the Indonesian Islamic Propagation Institute (LDII) journalistic activities at the national level is handled by the department of communications, information and media; at the provincial level by communication agency, Information and Media; and at the district or town by the communication part, Information and Media.

Its existence is equivalent to the ministry, bureau, or other parts, which both have their own methods for achieving the goals of da'wah. It id clearer form of propaganda press, where his journalistic activities handled by Field Garapan (Bidgar). While preaching purpose in doing well by 
bidgar others (who do not perform journalistic activities). Journalistic organizations is part of all missionary activity as shown in the management hierarchy of the organization (institution) message.

\subsection{Principles of Journalism}

In journalism, to achieve the expected objectives require the principles underlying the whole journalism. The principles of journalism include:

\section{a. Speed}

Journalism adheres to the principles of speed. Meaning, speed in which information can be immediately accepted by journalists and quickly disseminated through the mass media. Free reporters covering an event or to obtain news is influenced by the ability of journalists. The ability owned by the reporter is obtained through the knowledge and experience possessed by the reporter.

\section{b. Accuracy}

The accuracy of a media in presenting the news will attract people to read the media. The accuracy in presenting this news could be influenced by the good cooperation between the editorial management, business management, and management of printing. The one drawback, and the third part will affect the precision of the mass media to present the news.

\section{c. Competence}

Competence is defined as the ability of people in the running his duty. The ability of people influenced by educational background and also owned experience. It needs various disciplinary backgrounds, both social, economic, political, legal, and others. With a wide range of disciplines will help in analyzing highly complex problems that exist in society.

\section{d. Emphasis}

The emphasis here is defined as the principal issue that wants presented and reviewed in the mass media. Each media can provide emphasis in accordance with the respective features. Whether a media will hit the news in a particular field, such as social, economic, political, entertainment, sports, and others. Emphasis information submitted will make people look typical of the media concerned.

\section{e. Loyalty}

This loyalty greatly affects the growth of a body .Loyalitas in publishing journalism instance starts and journalists covering the news to the people who spread its product circulation. The loyalty of someone in their duties and can be influenced by factors within the person himself or outside 
form of management imposed on the company. Good management will encourage someone to continue loyal to the tasks in hand.

\section{f. Eligibility}

Feasibility becomes one of the principles in journalism. Eligibility here is about information received by the editorial. Whether a news or information contained worthy to be preached to the masses depending on the assessment on the part of the editors. Given the mass media is media that is enjoyed by the public, then the feasibility of an information or news that is published based on the common standards concerning the many and not just the interests of a particular person. Eligibility and a message to be loaded can also be viewed and morally as not to hurt the person or entity, not incite, polite language, and so on.

\section{g. Priority}

Priority has also become an important principle in jurnalistik. Priorityis in achieving the objectives. Often a press publishing company which has its own printing equipment in addition to print media, sometimes also for other businesses. In certain situations often occurs in common time for going to press. In such situations, it is necessary priority in the printing business is to put the print media as the main objective of the company.

There are three things that the message of the Quran to the process of presenting journalism so that it always has meaningful to humans. The first invites a way that is done and in accordance with the conditions of the object of propaganda, the second man as the object of the mission is plural and the plural it should be a consideration in formulating message, the third is a culture that can not be eliminated in the midst of society is cultural mimic (culture of followership), should a journalist care to cultural behavior with what it proposes, in accordance with the concept of journalism in the Qur'an. One of the functions of journalism is as defenders of truth and fairness. Many people refer to it as a universal function and ideal. A journalist is never asked to provide information, but it is its own initiative.

\section{DISCUSSION}

All journalistic activities is a missionary movement, with a record of what is written or published. The news which is published by a journalist is something that is da'wah, calling on the 
good and forbidding in the unjust. The journalist should use a polite language that reflects the da'wah.

There are few characteristics which becomes the distinguishing between the language used by the common journalistic compared with Islamic journalism, namely: simple, short, solid, straightforward, clear, clean, attractive, democratic, populist, logical, grammatical, avoid using words which is only understood by certain gourps such as "Atok" which means grandfather, avoid using foreign terms, using an appropriate word choice (diction), giving priority to active sentences, and finally as far as possible avoid to technical terms and must subject to the rules of ethics.

a. Simple

Simple means always prioritizing and selecting a word or phrase that is most widely known by an audience or readers who are very heterogeneous, in terms of intellectual level as well as demographic characteristics.

b. Brief

Brief means directly to the subject matter (to the point), not long-winded, do not spin, and do not waste the reader's time is very valuable.

c. Solid

According to Patmoko, SK, senior editor of Rays of Hope in the book of Journalism Techniques, solid in journalistic language means every sentence and paragraphs must consist of a lot of important and interesting information for the audience. It means there is a clear distinction between short sentences and phrases.

d. Unadorned

Means straightforward, unambiguous, avoiding euphemisms or smoothing words and sentences.

e. Clear

Clear means easily captured intention which is not diffuse and vague. As an example, black is a clear color, white is a clear color, but when these two colors put colesely it is a clearer which one is called black and which one is white.

\section{f. Transparent}

Transparent means honest, sincere, does not hide anything such as prejudice or slander.

g. Interesting 


\section{Budapest International Research and Critics Institute-Journal (BIRCI-Journal) \\ Volume I, February 2018, Page: 01-10 \\ e-ISSN: 2615-3076(Online), p-ISSN: 2615-1715(Print) \\ www.birci-journal.com \\ emails;birci.journal@gmail.com andbirci.journal.org@gmail.com}

Language journalism must be interesting. Exciting means able to generate interest and borders audience of readers, triggering appetite read, and make people who are asleep, awake instantly. Language journalism rests on the principle of exciting, true and raw.

h. Democratic

One of the most prominent characteristic of language journalism is democratics. Democratic means language journalism is not familiar with the language level, rank, caste or other distinction and greet parties as found in the grammar of Sundanese and Javanese.

i. Populist

Populist means any word, term or any sentence contained in the works of journalism should be familiar in the ears, eyes, and minds of an audience or readers. Language journalism must be populist, means acceptable and familiar to all levels of society.

j. Logic

Logic means anything contained in words, terms, sentences or paragraphs journalism should be acceptable and not contrary to common sense.

k. Grammatical

Grammatical means words, any term or phrase used and selected in language journalism must follow standard rules of grammar.

1. Avoid Using Speech Language

Speech language is the word commonly used in everyday conversation informally. Speech language is words that are spoken in the coffee shop, including a city bus, or in the market.

m. Avoid using foreign words and terms.

n. Choice an appropriate word (diction).

o. Stresses at active sentence.

Active voice is more easily understood and more preferably by an audience or readers rather than the passive voice.

p. Avoid using technical terms.

q. Subject to the rules of ethics. 


\section{Budapest International Research and Critics Institute-Journal (BIRCI-Journal) \\ Volume I, February 2018, Page: 01-10 \\ e-ISSN: 2615-3076(Online), p-ISSN: 2615-1715(Print) \\ www.birci-journal.com \\ emails;birci.journal@gmail.com andbirci.journal.org@gmail.com}

\section{CONCLUSION}

From the research and observations made by researcher, it can be concluded that there are some basic concepts offered by the Al-Quran through this journalism namely; Qaulan ma'rufan means the correct pronunciation, Qaulan Kariman means the polite word (Surah Al-Isra ': 23), Qaulan Maysuran means appropriate greeting (Surat al-Isra': 28), Qaulan Balighan means greeting appropriate to the circumstances ( Surah An-Nisa: 63), Qaulan Layyinan is gentle greeting (Surah Ta Ha: 44). Al-Quran contains of many journalistic elements which can be divided into four namely: Fairness accuracy (to be fair), the accuracy of the information, responsible, and constructive criticism.

\section{REFERENCES}

Al-Qur 'an Al 'Karim.

Abdullah.W awasan Dalcwah Kajian Epistimologi. Konsep dan Aplikasi Dakwah. Medan. IAIN.Press, 2002.

Arifin, M. Psikologi DakwahSuatu Pengantar Studi. Jakarta. Bumi Aksara, 1991.

Au, Fachry, dkk. Politik. Komunikasi Harmoko, Dan Rakyat ke Panggung Politik. Jakarta. Intermassa, 1997.

Anto, J. Dkk. Pers Bebas Tapi Dilibas. Medan. KIPPAS, 2005.

Arifin, Zainal Thoha. Menulis Karena Aku Ada.Yogyakarta.Kutub, 2005.

Assegaff H. Djafar. Jurnalistik Masa Kini (Pengantar ke Praktek Kewartawanan). Jakarta. Ghalia Indonesia, 1982.

AsSiddiqiye.Hasbi.Tafsir Al-Quran AnNur. Jakarta. Bulan Bintang, 1972.

Cangram Hafied. Pengantar ilmu Komunikasi. Jakarta. Rajawali Press,2005.

Djen,M. Amar. Hukuman Komunikasi Jurnalistik. Bandung. Diponegoro, 1984.

Darmadi, Z. Bambang, dkk. Mahir Berfurnalistik. Yogyakarta.Amara Books, 2005.

Departemen Agama RI. Al-qur 'an dan Terjemahan. Semarang. Toha Putra,1995.

Effendi, Onong Uchjana, 1986.Dimensi-dimensi Komunikasi.Bandung : Alumni. 1986. ,2001.Dinamika Komunikasi. Bandung : Remaja Rosda Karya. 2001. , 2002.Hubungan Masyarakat Studi Komunikologis.Bandung : Remaja Rosda Karya.2002.

Fraser, Bond F. Pengantar Jurnalistik. Bandung. Karya Nusantara, 1961. 


\section{Budapest International Research and Critics Institute-Journal (BIRCI-Journal) \\ Volume I, February 2018, Page: 01-10 \\ e-ISSN: 2615-3076(Online), p-ISSN: 2615-1715(Print) \\ www.birci-journal.com \\ emails;birci.journal@gmail.com andbirci.journal.org@gmail.com}

Hakim, Abdul Hasan Binjai.Tafsir Al-Abkam.Jakarta. Pernanda Media Group,2006.

Hernowo.Main-main dengan Teks. Bandung. Karfa, 2004.

Hans, AS. Sumadiria.Bahasa Jurnalistik. Yogyakarta.Simbiosa Rekatama Media, 2006.

HAMKA.Tafsir Al-Az̧har. Jakarta. Pustaka Panjimas, 1996.

Ibnu, Katsyir. Makna Lafadz Qori’. Bandung. Pustaka Hati, 1993.

IRM, PIP. Buku Panduan. www.akubisamenulis. Yogyakarta.PPIRM,2007.

Indriyanti, Amalia. Belajar Jurnalistik Teori dan Praktek. Bandung. Reihaja Rosda Karya, 2006.

Katie, Jamaludin, 1993, Psikologi Dakwah. Surabaya : Indah Surabaya.

Kholil, Syukur. 2007. Komunikasi Islami. Bandung: Citapustaka Media

Kuswata, R. Agus Toha, dkk, 1990. Komunikasi Islam dari Zaman ke Zaman. Jakarta: Ari kha Media Cipta.

Mahtudz, Syekh Ali. 1975. Hidayat Al-Musydin Ila Iburuqi al Wadli wa Kitbah. Mesir: Ustmaniah.

Muis, Abdul, 2001. Komunikasi Islam. Bandung: Remaja Rosdakarya

Moleong, Lexy, 2000. Metode Penelitian Kualitatif. Bandung: Remaja Rosda Karya.

Mubarok, Achmad, 1997. Psikologi Dakwah. Jakarta: Pustaka Pirdaus.

Mufid, Muhammad, 2006. Komunikasi dan Regulasi Penyiaran. Jakarta: Kencana.

Rakhmat, Jalaludin, 2001. Psikologi Komunikasi. Bandung: PT. Remaja Rosdakarya.

Rousydy, T.A. Lathief, 1985. Dasar-Dasar Retorika Komunikasi dan Informasi. Medan: Firma Rimbow..

Syukir, Asmuni. 1983. Dasar-Dasar Strategi Dakwah Islam. Surabaya: Al-Ikhlas.

Kusuma, Hikmat Ninggrat. Jurnalistik Teori dan Praktek.Bandung. Remaja Rosda Karya,2006.

Mappatoto, Andi Basao. Siaran Pers Suatu Kiat Penulisan. Jakarta. Gramedia Pustaka Utama, 1993.

Laksana, Rivers, dkk. Media Massa Dan Masyarakat Modern. Jakarta. Prenada Media, 2003.

Moenthadim, Martin SM.Jurnalistik. Tujub Menu.Yogyakarta.Andi, 2006.

Mubarok, Achmad. Psikologi Dakwah. Jakarta. Firdaus, 2001.

Muchlisin, Badiatul Asti. Da’i Bersenjata Pena. Bandung Ulumuddin, 2005.

Mulkhan, Abdul Munir. Paradigma Intelektual Muslim.Yogyakarta.Sipress, 1993.

Mustafa, Ahmad Al-Maraghi. Tafsir Al-Maraghi. Semarang. CV.Toha Putra, 1974.

Parapat, Rochimah. Jurnalistik Pembangunan. Medan. Nasional, 1985. 
Syamsul, Asep M.Romli. Jurnalistik Dakwan Vlsi dan Misi Dakwah bilQalam. Bandung. Remaja Rosda Karya, 2003.

Ya'qub, Hanizah, 1992, Publistik Islam, Teknik Dakwah dan Leadersip. Bandung: Cv. Diponigoro.

Yusuf, M. Yunan. 2006. Metode Dakwah: Sebuah Pengantar Kajian "Pengantar dalam Muhammad Munir. Jakarta. Kencana.

Rousdy, T.A Latief. 1989. Dasar-Dasar Rethorika Komunikasi dan Informasi. Medan Rinbow

Muhtadi. Asef Saiful. 1999. Jurnalisrik Pendekatan Teori dan Praktek. Jakarta: Logos

Sahroni, 1991. Sikap Berorganisasi, Cara Pandang Para Jurnalis. Jakarta: Al Bayan

Sophian, Ainur Rofiq. 1992. Tantangan Media informasi Islam Antara Profesionalisme dan Dominasi Zionis. Surabaya:Risalah Gusti

Uchjana Efendi, Onong,. 1999. Ilmu Komunikasi Teori dan Praktek. Bandung: Rosdakarya

Natsir, HM. Makalah: Manajemen Penyiaran Radio. Disampaikan Pada Pendidikan dan Latihan Reportase Pkan Baru tanggal 19 Agustus s/d 8 September 2001

Rakhmat, Jalaluddin, 1993. Psikologi Komunikasi. Bandung: Remaja Rosdakarya ,

------1994. Islam Aktual; Bandung: Remaja Rosdakarya

MS. Wahyudin, 1991. Memahami Konsep Sikap Secara Integral. Bandung: Al Insan

Widodo. 1997. Teknik Wartawan Menulis Berita di Surat Kabar dan Majalah.

Surabaya: Indah.

Yahya, Thaha Umar. Imu Dakwah.Jakarta. Wijaya, 1983.

Yunus, Mahmud. Pedoman Dakwah Islamiyah. Jakarta. Hidakarya Agung, 1965.

Tafsir Qur 'anulKarim. Jakarta. Hidakarya Agung, 2000.

Roland, E. Wolseley. Understanding Magazines. Nederlands. Diurnalis Press, 1969. 
